\title{
ВПЛИВ ПАРАМЕТРІВ СИСТЕМИ АКУМУЛЮВАННЯ ЕЛЕКТРОЕНЕРГІЇ НА БАЛАНСУВАННЯ КОМБІНОВАНОЇ ЕНЕРГОСИСТЕМИ
}

\author{
М.П. Кузнєцов ${ }^{1}$, д-р техн. наук, О.А. Мельник ${ }^{2}$, аспірант, В.М. Смертюк ${ }^{1}$, аспірант \\ ${ }^{1}$ Інститут відновлюваної енергетики НАН України, \\ 02094, вул. Гната Хоткевича, 20А, м. Київ, Україна. \\ ${ }^{2}$ Національний технічний університет України «Київський політехнічний інститут ім. Ігоря Сікорського», \\ 03056, пр-т Перемоги, 37, м. Київ, Україна.
}

Метою даної роботи є дослідження впливу таких параметрів системи акумулювання електроенергії, як ємність та швидкодія, на стан балансу потужностей в комбінованій енергосистемі. Особливістю комбінованої локальної системи є значні градієнти поточної потужсноті, обумовлені змінною природою вітрових і сонячних електростанцій. Система акумулювання енергії має максимально збалансувати генерацію та споживання електроенергії, зменшити втрати можливоі надлишкової енергії чи їі дефіцичт. Об'єкт дослідження - гібридні електроенергетичні системи, які мають властивості локальної мережі. Елементами системи є вітрові та сонячні електростаниії та засоби акумулювання енергї, здатні реагувати на швидкі зміни потужності. Методом дослідження є математичне моделювання випадкових процесів споживання та генерачії енергії, яке дозволяє аналізувати поточне балансування потужностей та отримувати інтегральні характеристики стану акумулювання і повторного використання енергї̈. Моделювання режимів роботи сонячних і вітрових електростаниій основане на статистичних даних про погодні фактори, а балансування потужності можна розглядати як суперпозицію випадкових процесів генерачії та споживання. Особливістю дослідження є одночасне врахування швидких змін потужності вітрових і сонячних електростанцій, можливостей накопичення незбалансованої енергї̈ та реального стану зарядки акумуляторів. Аналітичне дослідження потребує точного визначення характеристик розподілу ймовірності для кількох випадкових процесів, тому використано адаптивну імітаційну модель з можливістю варіації вхідних параметрів. Застосована модель енергобалансу дозволяє імітувати процес акумулювання енергії та розрахувати поточні й кумулятивні показники. В результаті дослідження встановлено вплив ємності та швидкодії акумуляторів на енергетичну ефективність системи. Визначено області чутливості енергетичного балансу, коли швидкість зарядки акумуляторів стає меншою за швидкість поточних змін вітрової та сонячної потужності. Порівнюються різні конфігурації енергосистеми за джерелами енергії, при цьому враховуються географічні відмінності й сезонні кліматичні особливості. Бібл. 16, табл. 3 , рис. 4.

Ключові слова: гібридна енергосистема, відновлювані джерела енергї̈, баланс потужності, випадковий прочес,

акумулювання електроенергіi.

\section{INFLUENCE OF ELECTRICITY ACCUMULATION PARAMETERS ON THE COMBINED POWER SYSTEM BALANCING}

\author{
M. Kuznietsov ${ }^{1}$, doctor of technical science, $\mathbf{O}$. Melnyk $^{\mathbf{2}}$, graduate student, V. Smertiuk ${ }^{\mathbf{1}}$, graduate student \\ ${ }^{1}$ Institute of Renewable Energy of the National Academy of Sciences of Ukraine, \\ 02094, 20A Hnata Khotkevycha St., Kyiv, Ukraine. \\ ${ }^{2}$ National Technical University of Ukraine «Igor Sikorsky Kiev Polytechnic Institute», \\ 03056, 37 Peremohy Av., Kyiv, Ukraine.
}

The purpose of the paper is to estimate influence of the electric energy storage system indicators, such as batteries capacity and charging speed, on the combined power system balancing. A feature of the combined local system is the significant current power gradients due to the changing nature of wind and solar power plants. The energy storage system should balance the generation and consumption of energy as much as possible, reduce the loss of possible excess energy or its deficit. The object of research is hybrid electrical systems with local network properties. Wind and solar power plants are the elements of such system, and energy storage devices are able to respond to rapid power changes. The research method is mathematical modeling of random processes such as energy consumption and generation, which allows us to analyze the current balancing of capacities and integral energy storage-reuse characteristics. Modeling the operating modes of solar and wind power is based on statistical weather data. The balancing of capacities can be considered as a superposition of random processes of generation and consumption. A features of the study is taking into account 
the simultaneous changes in the wind and solar power, the possibility of accumulating unbalanced energy and the real state of battery charging. An analytical study requires an accurate determination of the probability distribution for several random processes, therefore an adaptive simulation model with variations in input parameters is used. The energy balance model was applied, which allows us to simulate the process of energy storage and to evaluate current and cumulative indicators. As a result, the influence of the capacity and charging speed of batteries on the system energy efficiency was established. The areas of sensitivity of the energy balance are determined when the rate of battery charging becomes less than the current changes in wind and solar power. Various power system configurations are compared by energy source, taking into account seasonal climatic features. Bibl. 16, tab. 3, fig. 4.

Keywords: hybrid power system, renewable energy sources, power balance, random process, energy storage.

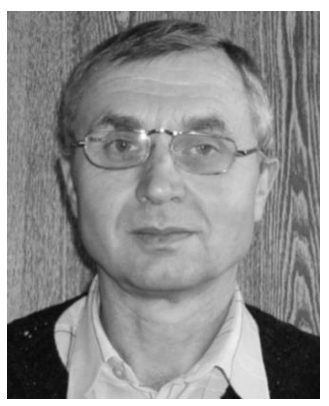

М.П. Кузнєцов M. Kuznietsov

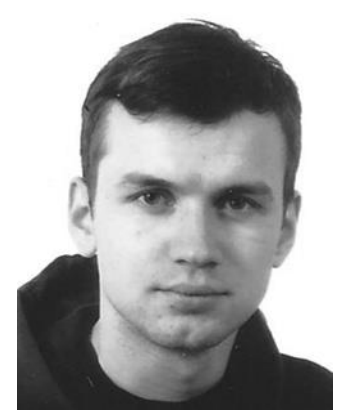

О.А. Мельник O. Melnyk

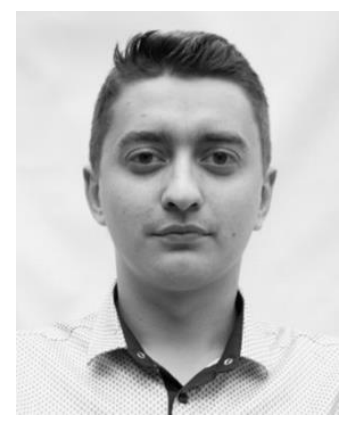

B.M. Смертюк V. Smertiuk
Відомості про автора: заступник директора Інституту відновлюваної енергетики НАН України, старший науковий співробітник, доктор технічних наук

Освіта: Київський державний університет ім. Т. Шевченка, мех.-мат. факультет

Наукова сфера: математика, відновлювана енергетика

Публікації: 95

ORCID: 0000-0002-0497-7439

Контакти: тел./факс: +38(044)206-28-09

e-mail: renewable@ukr.net

Відомості про автора: аспірант, інженердослідник

Освіта: Національний технічний університет України «Київський політехнічний інститут ім. І. Сікорського», факультет електроенерготехніки та автоматики Наукова сфера: електроенерготехніка, відновлювана енергетика

Публікації: 16

ORCID: 0000-0003-2894-3476

Контакти: тел./факс: +38(044)236-21-49

e-mail: aspirantura@kpi.ua

Відомості про автора: аспірант, інженердослідник

Освіта: Національний технічний університет України «Київський політехнічний інститут ім. І. Сікорського», факультет електроенерготехніки та автоматики Наукова сфера: електроенерготехніка, відновлювана енергетика

Публікації: 6

ORCID: 0000-0001-9224-7403

Контакти: тел./факс: +38(044)206-28-09

e-mail: smertykvn@gmail.com
Author information: Deputy Director of the Institute of Renewable Energy at the NASU, Doctor of technical sciences

Education: Taras Shevchenko Kyiv State University, Faculty of Mechanics and Mathematics

Research area: mathematics, renewable energy Publications: 95

ORCID: 0000-0002-0497-7439

Conatacts: tel./fax: +38(044)206-28-09

e-mail: renewable@ukr.net

Author information: graduate student, research engineer

Education: National Technical University of

Ukraine "Igor Sikorsky Kyiv Polytechnic

Institute", Faculty of Electric Power Engineering and Automatics

Research area: electric power engineering, renewable energy

Publications: 16

ORCID: 0000-0003-2894-3476

Contacts: tel./fax: +38(044)236-21-49.

e-mail: aspirantura@kpi.ua

Author information: graduate student, research engineer

Education: National Technical University of Ukraine "Igor Sikorsky Kyiv Polytechnic Institute", Faculty of Electric Power Engineering and Automatics

Research area: electric power engineering, renewable energy

Publications: 6

ORCID: 0000-0001-9224-7403

Contacts: tel./fax: +38(044)206-28-09

e-mail: smertykvn@gmail.com

Перелік використаних скорочень та позначень:

АКБ - акумуляторна батарея;

ВДЕ - відновлювані джерела енергії;

ГАЕС - гідроакумулююча електростанція;

СКВ $(\sigma)$ - середньоквадратичне відхилення;

HRES - гібридна енергосистема з ВДЕ;

BESS - система акумулювання енергії;

$C$ - ємність акумулятора (в.о.-год.);

$k$ - показник швидкості повної розрядки (1/год.);

$p_{i}$ - поточна потужність (в.о.);

$E_{\Delta}$ - накопичена енергія небалансу (в.о.-год.);

$E_{t o t a l}$ - загальна збережена енергія (в.о.-год.). 
Вступ. Використання систем накопичення та повторного використання надлишкової енергії $€$ вживаним засобом забезпечити збалансованість попиту та пропозиції в локальній енергосистемі. Особливо це стосується комбінованих (гібридних) систем генерації, де використовуються вітрові електростанції (ВЕС) та сонячні електростанції (CEC). Задача акумуляторних батарей в таких системах - убезпечити споживача від надмірних коливань потужності та запобігти втратам енергії при надмірній генерації й обмеженому споживанні. Споживачі, локалізовані на кінцевих вітках електромереж, таким чином, забезпечують надійність енергопостачання та захищають мережу від негативного впливу небалансів потужності. Для автономних споживачів використання акумуляторів $є$ необхідною умовою стабільного енергозабезпечення. Режими генерації ВЕС та СЕС характеризуються істотними коливаннями поточної потужності в обмежених часових рамках, що накладає специфічні вимоги до загальної ємності та швидкодії акумуляторів. При цьому мають враховуватися реальні характеристики вітрової та сонячної генерації, які мають географічні відмінності та сезонні особливості.

Стан дослідження проблеми. Проблеми балансування потужності в гібридних енергосистемах 3 відновлюваними джерелами енергіï (Hybrid Renewable Energy Systems - HRES) розглядаються в багатьох публікаціях, які стосуються інтегрування відновлюваної енергетики [1]. Предметом досліджень зазвичай $\epsilon$ оптимальна конфігурація та вибір параметрів відновлюваних джерел i допоміжних акумуляторних систем накопичення енергії (Battery Energy Storage Systems - BESS) [2]. Якщо використання відновлюваної енергії в гібридних системах може значно покращити екологічну ефективність електропостачання, то BESS слугують для підвищення надійності та економічної ефективності, особливо для децентралізованих споживачів. Це істотно, оскільки електростанції на основі вітрової та сонячної енергії можуть розташовуватися якомога ближче до місця кінцевого споживання енергії.
Найбільш складними 3 точки зору енергетичного менеджменту $\epsilon$ системи 3 високим рівнем проникнення ВДЕ [3]. Обов'язковим елементом таких енергетичних систем має бути пристрій накопичення енергії та їі доставки споживачам під час відсутності зовнішньої генерації. Характерною особливістю режимів роботи HRES, особливо 3 високим проникненням ВДЕ, $\epsilon$ широкий діапазон змін генерованої та споживаної потужності через різні інтервали часу, що спричинює наявність пульсацій у струмах зарядурозряду BESS. Негативний вплив таких факторів на роботу обладнання розглянуто в ряді публікацій (див. напр. [4]). Враховуючи високу вартість BESS, ця обставина набуває особливої ваги [5]. Для досягнення максимальної ефективності HRES та збільшення часу автономної роботи пропонуються різні топології HRES [6], розробляються нові методи контролю та управління споживанням енергії [7], нерідко 3 використанням складних інтелектуальних алгоритмів [8].

Одним із популярних способів підвищення ефективності BEES $€$ комбінування накопичувачів енергії з різними технічними характеристиками $[9,10]$. Традиційно в локальних енергосистемах невеликого обсягу як накопичувач енергії розглядають електрохімічні АКБ. Ці батареї в свою чергу охоплюють значну кількість типів 3 різноманітними властивостями, які наразі вважаються досить вивченими. Електрохімічні акумулятори можуть істотно відрізнятися за такими параметрами, як номінальна потужність та ємність, життєвий цикл, енергетична ефективність зарядки/розряду (або коефіцієнт корисної дії - ККД), час повного розряду (швидкодію) та ін. [11]. Ці параметри є важливими в умовах застосування ВДЕ, які передбачають швидку зміну балансу потужності та часту зміну режимів роботи, тобто передбачають особливі вимоги до швидкодії (часу реагування та зарядки/розряду). Час реагування таких АКБ вимірюється секундами, а розряду - годинами. Що стосується допустимої глибини розрядки, то для розрахунків достатньо під ємністю АКБ мати 
на увазі лише робочий обсяг накопиченої енергії, вважаючи його змінним від нуля до максимуму.

Постановка завдання. В цитованих джерелах розглядаються конкретні системи й типи обладнання; актуальним $є$ створення адекватної математичної моделі, в якій параметри системи були б формалізованими і допускали широкий спектр можливостей для обрання найбільш оптимальних варіантів. Приклад розробки такої моделі наведено в роботі [12], продовженням якої $\epsilon$ дана стаття. Показник максимальної швидкості зарядки накладає обмеження на обсяг накопиченої енергії. Це обмеження у вигляді допустимого в даний момент струму зарядки пропорційне кількості незаповненої ємності акумулятора. Їх залежність звичайно описується рівняннями, параметрами яких є час, максимальна ємність, поточний заряд, допустима глибина розряду, внутрішня пропускна здатність (швидкість перетворення електричної енергії на хімічну i навпаки). Можливість утилізації надлишкової енергії визначається як поточним рівнем зарядки акумулятора, так i допустимою швидкістю зарядки, яка має перевищувати темп наростання (градієнт) потужності. Сказане стосується електрохімічного акумулятора, проте обмеження на швидкість заряджання властиве різним технологіям накопичення енергії. В ідеалізованій моделі можна вважати швидкодію певною осередненою сталою, враховуючи зокрема можливу наявність кількох акумулювальних одиниць з різним рівнем заряду. Звичайно показником швидкодії $\epsilon$ час, протягом якого можна повністю розрядити номінальну ємність (на практиці акумулятор може бути розряджений лише до певного рівня). Тоді швидкість розряду задається ємністю акумулятора, поділеною на кількість годин, необхідних для зарядки/розряду акумулятора. Отже, показник швидкодії є оберненою до часу величиною: $k=1 / t$, де $t-$ час у годинах. Смність акумулятора звичайно позначають як $C$ (Capacity), а швидкодію можна записати як $k C$. Відповідно запис $6 C$ означає час зарядки/розряду 10 хв. Малі акумулятори звичайно розраховані на $1 C$, свинцево-кислотні акумулятори оцінюють як $0,2 C$
(5 год.) чи 0,05C (20 год.). Варіюючи параметрами $C$ (повна ємність) та $k$ (швидкодія), за математичною моделлю [12] можна оцінити ефективність збереження надлишкової енергії, запобігання втратам навантаження, імовірність вказаних явищ тощо.

Результати дослідження. Як свідчить аналіз статистичних даних, поточна потужність генерації ВДЕ та споживання характеризуються наявністю деякого осередненого добового ходу та випадкових відхилень (флуктуацій), які $\epsilon$ функціями часу. Ці флуктуації можна вважати взаємно незалежними випадковими величинами, враховуючи відсутність кореляції між короткочасними (в хвилинному діапазоні) коливаннями сонячної, вітрової енергії та споживання [13]. Оскільки одиничні стрибки потужності (зміни за елементарний інтервал часу $\Delta t)$ мають обмеження через фізичні властивості електричного обладнання, то процес відхилення від середнього значення можна представити як дискретну модель блукання, де поточні значення перебувають у певному коридорі. В узагальненому вигляді такий процес $P(t)$ може бути описаний виразом [14]:

$$
p_{i}=\alpha p_{i-1}+\eta \varepsilon_{i}, p_{i}=1 / \Delta t \cdot \int_{t_{i}}^{t_{i}+\Delta t} P(t) d t
$$

де $\alpha, \eta-$ деякі числові параметри, що характеризують випадковий процес; $\varepsilon$ - стандартна нормальна випадкова величина.

Виразом (1) неперервний процес представлено дискретним, послідовністю осереднених на елементарному часовому проміжку значень. В даному дослідженні випадковим процесом вважаємо балансування генерованої потужності та навантаження, тоді позитивний небаланс виражає надлишкову генерацію, а негативний - втрату споживання. За одиничну реалізацію випадкового процесу прийнято добовий набір 10-хвилинних даних, тобто впорядковану послідовність 144 значень. Надалі потужність небалансу врахована як середні значення в кожному 10-хвилинному інтервалі, а акумульована енергія визначається як ї кумулятивна сума 3 урахуванням тривалості інтервалу: 


$$
E_{\Delta}\left(t_{i}\right)=\sum_{n=1}^{i} p_{i} \Delta t
$$

Розглянемо окремо вплив обмежень акумулятора на обсяги накопиченої енергії під час роботи ВЕС та СЕС незалежно від режиму споживання. Вважається, що споживання протягом доби детерміноване, i дорівнює середньомісячному тренду відповідного виду ВДЕ. Тоді акумулювання стосуватиметься випадкових відхилень від графіка навантаження. Оскільки графік навантаження побудований на основі багаторічних даних для певного місяця (місячна циклічність), то кожна окрема реалізація за середнім добовим значенням може відрізнятися від середньомісячного, отже, як показники розкиду значень генеральної сукупності реалізацій розглядаємо СКВ повного, тобто місячного, набору даних - $\sigma_{N}$, а також середні значення добових варіацій $\sigma_{d}$, та міждобове СКВ, тобто розкид середньодобових значень - $\sigma_{a d}$. У разі, коли графік навантаження враховує щоденне прогнозування очікуваних середньодобових значень (добова циклічність), вважаємо: $\sigma_{a d}=0, \sigma_{N}=\sigma_{d}$.

Розглянемо ситуацію місячної циклічності. Для зручності номінальні потужності ВДЕ задано у відносних одиницях стосовно максимальної потужності споживання, умовно рівної відносній одиниці (в.о.). Для оцінки впливу окремо сонячної, вітрової генерації та їх комбінацій розглядаємо випадки одиничної потужності лише BEC (варіант B1) чи CEC (варіант C1), а також іх комбінації (B1, С1). Спочатку розглядаємо результати моделювання для різних місяців без урахування обмежень на засоби акумулювання, тобто оцінюємо повний обсяг надлишкової енергії. Застосовано не менше тисячі добових реалізацій випадкового процесу для кожного варіанту. Результати свідчать, що розподіл імовірності для повного набору поточних значень небалансу енергії, тобто кумулятивних сум потужностей (2), близький до Гаусового, хоча не відповідає усім критеріям нормальності. Математичне очікування нульове 3 огляду на прийняте припущення про місячну циклічність, а показники дисперсії мають деяку асиметрію: від $(-5)$ до (+9). Урахування лише одного виду ВДЕ робить асиметрію ще помітнішою. Так, для вітрової енергії щільність розподілу ближча до розподілу Вейбула, хоча при значних швидкостях вітру функції Вейбула та Гауса мають близькі значення в межах довірчого інтервалу. Наведені приклади характерні для сезонних умов, коли частки сонячної та вітрової генерації $\epsilon$ екстремальними. Для врахування умов міжсезоння розглянуто дані за квітень, який характеризується високими показниками обох джерел енергії, а їх середні значення близькі до середньорічних. Оскільки для квітня показники сукупної потужності ВДЕ виявилися найвищими впродовж року, саме для них було досліджено вплив характеристик акумулятора на обсяги накопичення енергії.

В табл. 1 наведено дані про дисперсію (точніше, середньоквадратичні відхилення) значень небалансу поточної потужності та кумулятивних значень енергії для різних варіантів ВДЕ.

Таблиця 1. Дисперсія небалансу без обмежень, квітень (в.о.)

Table 1. Imbalance variance without restrictions, April (relative units)

\begin{tabular}{|l|c|c|c|c|c|c|}
\hline \multirow{2}{*}{ Склад ВДЕ } & \multicolumn{3}{|c|}{ СКВ потужностей $p_{i}$} & \multicolumn{3}{|c|}{ СКВ енергї $E_{\Delta}$} \\
\cline { 2 - 7 } & $\boldsymbol{\sigma}_{\boldsymbol{N}}$ & $\boldsymbol{\sigma}_{\boldsymbol{d}}$ & $\boldsymbol{\sigma}_{\boldsymbol{a d}}$ & $\boldsymbol{\sigma}_{\boldsymbol{N}}$ & $\boldsymbol{\sigma}_{\boldsymbol{d}}$ & $\boldsymbol{\sigma}_{\boldsymbol{a d}}$ \\
\hline $\mathrm{B} 1, \mathrm{C} 0$ & 0,29 & 0,13 & 0,26 & 3,70 & 1,64 & 3,25 \\
\hline $\mathrm{B} 0, \mathrm{C} 1$ & 0,12 & 0,09 & 0,07 & 1,07 & 0,62 & 0,80 \\
\hline $\mathrm{B} 1, \mathrm{C} 1$ & 0,31 & 0,16 & 0,26 & 3,85 & 1,76 & 3,35 \\
\hline
\end{tabular}


Якщо порівнювати щільність розподілу 3 асиметрія (рис. 1), в межах від (-7) до (+8), та нормальною, то для довірчої імовірності 0,95 (варіант В1, С1) мали б бути відхилення в підвищений ексцес, проте розподіл вже близький межах \pm 6 . Насправді ще зберігається деяка

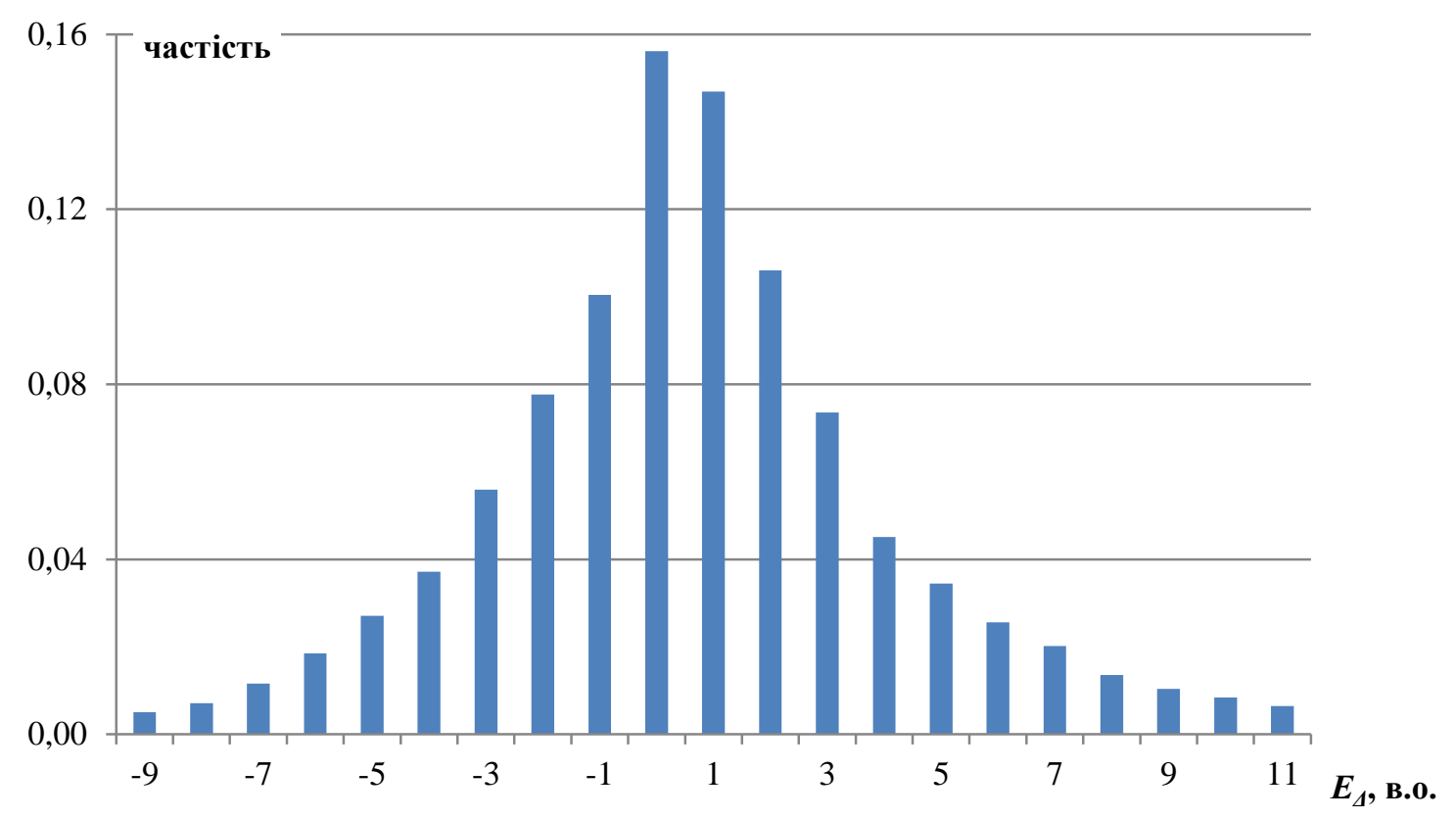

Рис. 1. Розподіл значень небалансу енергії (квітень, В1, С1)

Fig. 1. Distribution of energy imbalance (April, W1, S1)

Розглянемо вплив параметрів акумулятора $C$ та $k$ на показники балансування.

Якщо аналізувати всю сукупність даних імітаційної моделі, то одиничні небаланси потужності мають розмах $\pm 1,0$; накопичений небаланс змінюється в межах \pm 16 (в.о.). Виходячи 3 характеру розподілу імовірності, при ємності акумулятора $C<16$ може бути втрачено частину енергії при повному заряді, а обмеження в одиничному кроці почнуться при $\delta C=k C \Delta t<1$. Тобто для $C=16$ i $\Delta t=1 / 6$ має бути $k>0,4$ (час повної зарядки/розряду 2,5 год), або $k C / 6>3 \sigma_{N}$ за правилом «трьох сигм»; слід враховувати, що насправді як $C$ враховується $\left(C_{\max }-C_{\min }\right)$. Отже, на відміну від повного небалансу енергії $E_{\Delta}$ реально акумульована енергія буде обмежена граничними значеннями 0 i $C$, а також допустимим зростанням $\delta C$, тобто стан зарядки акумулятора в момент часу $t_{i}$ визначається умовами:

$$
C_{i}=C_{i-1}+p_{i} \Delta t, p_{i} \Delta t \leq \delta C, 0 \leq C_{i} \leq C .
$$

Оскільки протягом добової реалізації випадкового процесу поточна накопичена енергія може багатократно зростати та повертатись споживачу, про характер накопичення можна судити за середнім за добу рівнем зарядки акумулятора та відхиленням від середнього, при певній гіпотезі щодо функції щільності розподілу. Так, для варіанту B1, C1 при $C=16, k=6$ (тобто практично без обмежень за амплітудою) реальний стан акумулювання має середнє значення близько 1,4 з СКВ: $\sigma_{N}=2,5 ; \sigma_{d}=0,9 ; \sigma_{a d}=2,0$. Середне значення набагато менше досяжного діапазону, оскільки за умовою підсумковий баланс енергії нульовий (умова місячної циклічності), а отже, близько половини значень небалансу потужності від’ємні, тобто не акумулюються. Імовірність заповнення всієї доступної ємності практично нульова. При обмеженні темпу зарядки в певних межах розряд акумулятора також сповільнюється, в результаті середній рівень зарядки зберігається. Однак можливість накопичення надлишкової енергії зменшується тим істотніше, чим меншою $€$ 
швидкодія. Загальну кількість втраченої при цьому енергії можна визначити за щільністю розподілу [12]. Оскільки точний аналітичний опис щільності розподілу зробити складно, такі втрати визначено шляхом імітаційного моделювання.

Розглянемо вплив обмежених за темпом $(k)$ i ємністю $(C)$ можливих обсягів накопиченої енергії, враховуючи лише додатні небаланси. Оскільки 3 часом енергія як накопичується, так і витрачається, коливаючись навколо середнього рівня (див. рис. 1), розглянемо загальну суму надходжень енергії за добу, включаючи повторні накопичення: $E_{\text {total }}=\sum_{1}^{144}\left(C_{i+1}-C_{i}>0\right)$.

Перевищення над середнім рівнем зарядки свідчитиме про наявність кількох циклів зарядки/розряду протягом доби. Враховуємо всі наявні обмеження. Накопичувана протягом доби енергія як сума всіх позитивних надходжень наведена в табл. 2 (середні значення та СКВ) i зображена на рис. 2.

Таблиця 2. Імовірні накопичення енергії при обмеженнях на потужність АКБ (в.о.)

Table 2. Probable energy savings with battery power limits (relative units)

\begin{tabular}{|l|l|l|l|l|l|l|}
\cline { 2 - 7 } \multicolumn{1}{c|}{} & \multicolumn{3}{c|}{$E_{\text {total }}$} & \multicolumn{3}{c|}{ CKB } \\
\hline$C^{\mathbf{n}}$ & $\mathbf{0 , 0 3}$ & $\mathbf{0 , 0 5}$ & $\mathbf{2} \mathbf{0 , 0 8}$ & $\mathbf{0 , 0 3}$ & $\mathbf{0 , 0 5}$ & $\geq \mathbf{0 , 0 8}$ \\
\hline $\mathbf{1 6}$ & 2,86 & 3,03 & 3,10 & 3,53 & 3,75 & 3,92 \\
\hline $\mathbf{1 3}$ & 2,68 & 2,97 & 3,06 & 3,10 & 3,56 & 3,80 \\
\hline $\mathbf{8}$ & 2,32 & 2,89 & 3,02 & 2,57 & 3,25 & 3,52 \\
\hline $\mathbf{6}$ & 1,99 & 2,63 & 2,89 & 2,10 & 2,8 & 3,12 \\
\hline $\mathbf{4}$ & 1,59 & 2,15 & 2,47 & 1,63 & 2,25 & 2,50 \\
\hline $\mathbf{2}$ & 1,14 & 1,53 & 1,77 & 1,11 & 1,55 & 1,80 \\
\hline $\mathbf{1}$ & 0,70 & 0,94 & 1,10 & 0,63 & 0,9 & 1,05 \\
\hline
\end{tabular}

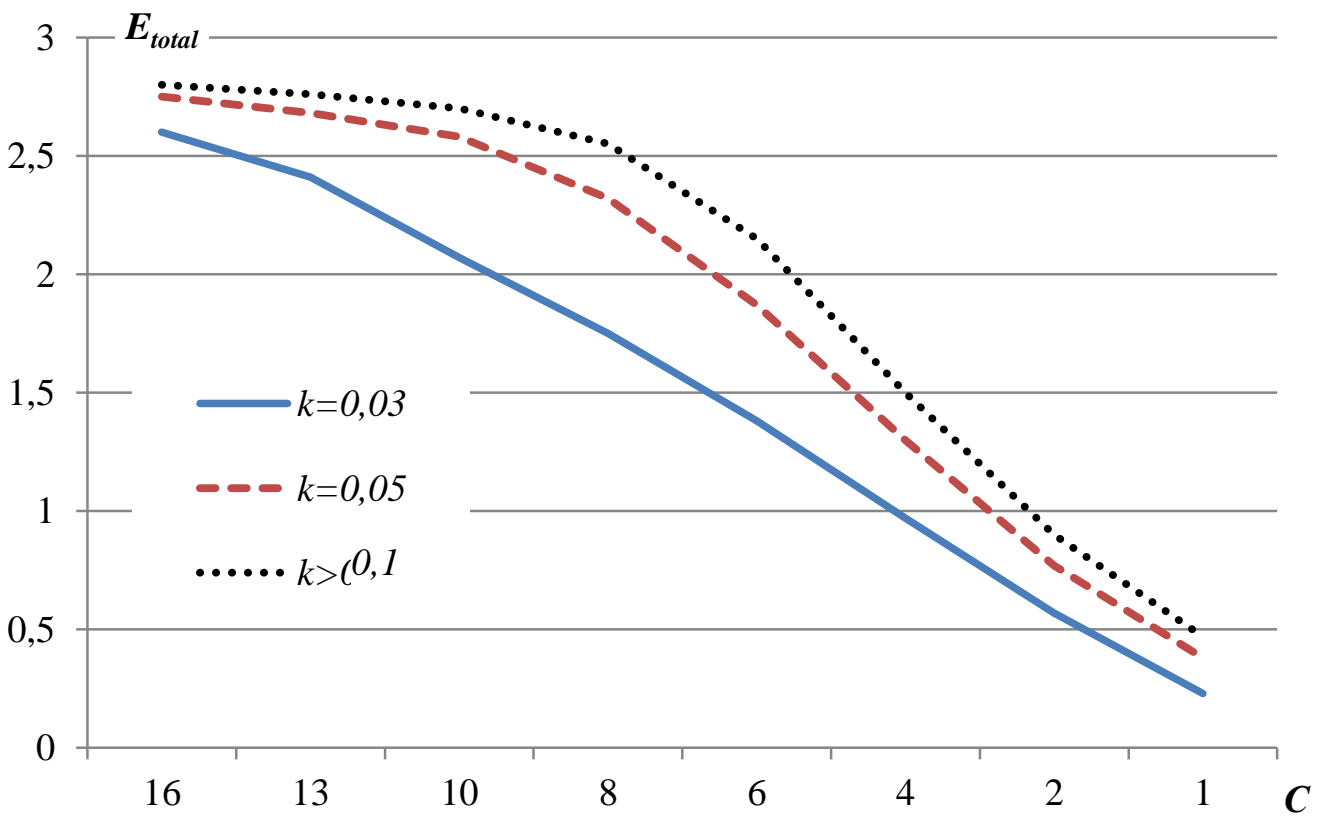

Рис. 2. Накопичення енергії залежно від ємності акумулятора, в.о.

Fig. 2. Accumulation of energy depending on the battery capacity, relative units 
Як бачимо, чутливість до обмежень за швидкодією акумулятора невисока, помітна для значень $k<0,1$ (тобто часу повної зарядки понад 10 год.), а залежність від ємності краще проявляється при малих значеннях наближаючись до лінійної.

Отримані значення накопичень енергії та імовірних втрат є математичним очікуванням при великій кількості (понад 1 тис.) реалізацій випадкового процесу; відповідні відхилення (СКВ) досить значні і мають якісно подібну до середніх значень поведінку.

Розглянемо ситуацію, коли на кожну добу $є$ точний прогноз середнього рівня споживання та генерації ВДЕ, якому відповідає плановий графік навантаження. Отже, умови добової циклічності:

$$
E_{\Delta}\left(t_{144}\right)=C_{144}=\sum_{1}^{144} P\left(t_{i}\right) \Delta t=0
$$

де $C_{1}=P\left(t_{1}\right) \Delta t-$ випадкова величина, незалежна від $C_{144}$ попередньої доби.

Під час моделювання процесу балансування варіації середньодобових значень потужності вважаємо відсутніми: $\sigma_{a d}=0$; однак характер накопичення енергії (кумулятивна сума) матиме відмінності для кожної реалізації, залежно від послідовності окремих значень потужності. Розглянемо вплив параметрів акумулятора за таких умов.

Якщо розглядати сукупність лише добових реалізацій моделі, то одиничні небаланси потужності для умов квітня, як і раніше, не перевищують 1,0 (в.о.). Максимально можливий накопичений протягом доби небаланс перебуває в

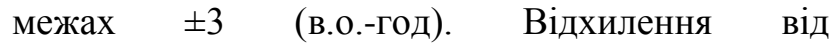
середньодобового навантаження за потужністю очевидно менші, ніж від середньомісячного, i близькі до $\sigma_{d}$ (див. табл. 2). Накопичена енергія має вже істотно менші значення. Обмеження на одиничний заряд (10-хвилинний максимум) лишаються такими самими, як і вище. Однак при менших абсолютних значеннях ємності вплив швидкодії акумулятора стає помітнішим, тому оцінка чутливості максимального накопичення до параметрів акумулятора має виконуватись 3 меншим кроком, для виявлення локальних особливостей. Результати моделювання за тих же умов (квітень, варіант В1, С1) наведено в табл. 3.

Таблиця 3. Накопичення енергї за умови добової циклічності (варіант В1,C1)

Table 3. Accumulation of energy under the daily cyclicity condition (option W1, S1)

\begin{tabular}{|c|c|c|c|c|c|c|c|c|c|}
\hline & $C$ & 1 & 0,5 & 0,3 & 0,2 & 0,1 & 0,07 & 0,05 & 0,03 \\
\hline \multirow{4}{*}{ 胥 } & 3 & 1,76 & 1,77 & 1,76 & 1,74 & 1,60 & 1,38 & 1,10 & 0,72 \\
\hline & 2 & 1,69 & 1,70 & 1,69 & 1,65 & 1,41 & 1,05 & 0,82 & 0,51 \\
\hline & 1 & 1,35 & 1,36 & 1,33 & 1,22 & 0,91 & 0,65 & 0,52 & 0,28 \\
\hline & $\mathbf{0 , 5}$ & 0,87 & 0,87 & 0,83 & 0,70 & 0,51 & 0,32 & 0,27 & 0,14 \\
\hline \multirow{4}{*}{ 孚 } & 3 & 0,55 & 0,53 & 0,52 & 0,50 & 0,45 & 0,40 & 0,31 & 0,20 \\
\hline & 2 & 0,58 & 0,59 & 0,56 & 0,51 & 0,41 & 0,33 & 0,23 & 0,14 \\
\hline & 1 & 0,33 & 0,32 & 0,32 & 0,41 & 0,20 & 0,18 & 0,10 & 0,07 \\
\hline & $\mathbf{0 , 5}$ & 0,23 & 0,23 & 0,21 & 0,18 & 0,10 & 0,09 & 0,05 & 0,03 \\
\hline
\end{tabular}

На відміну від місячної циклічності, при добовій більше помітною $\epsilon$ нелінійність для значень швидкодій акумулятора в межах $0,1<k<1,0$. Істотним такий вплив стає вже при $k<0,3$ (при місячній циклічності подібний ефект проявлявся лише при $k<0,1)$.

Слід відмітити, що шкала значень в табл. 2 не $€$ рівномірною. На логарифмічній за параметром $k$ шкалі накопичення енергії при різній ємності матиме такий вигляд (рис. 3): 


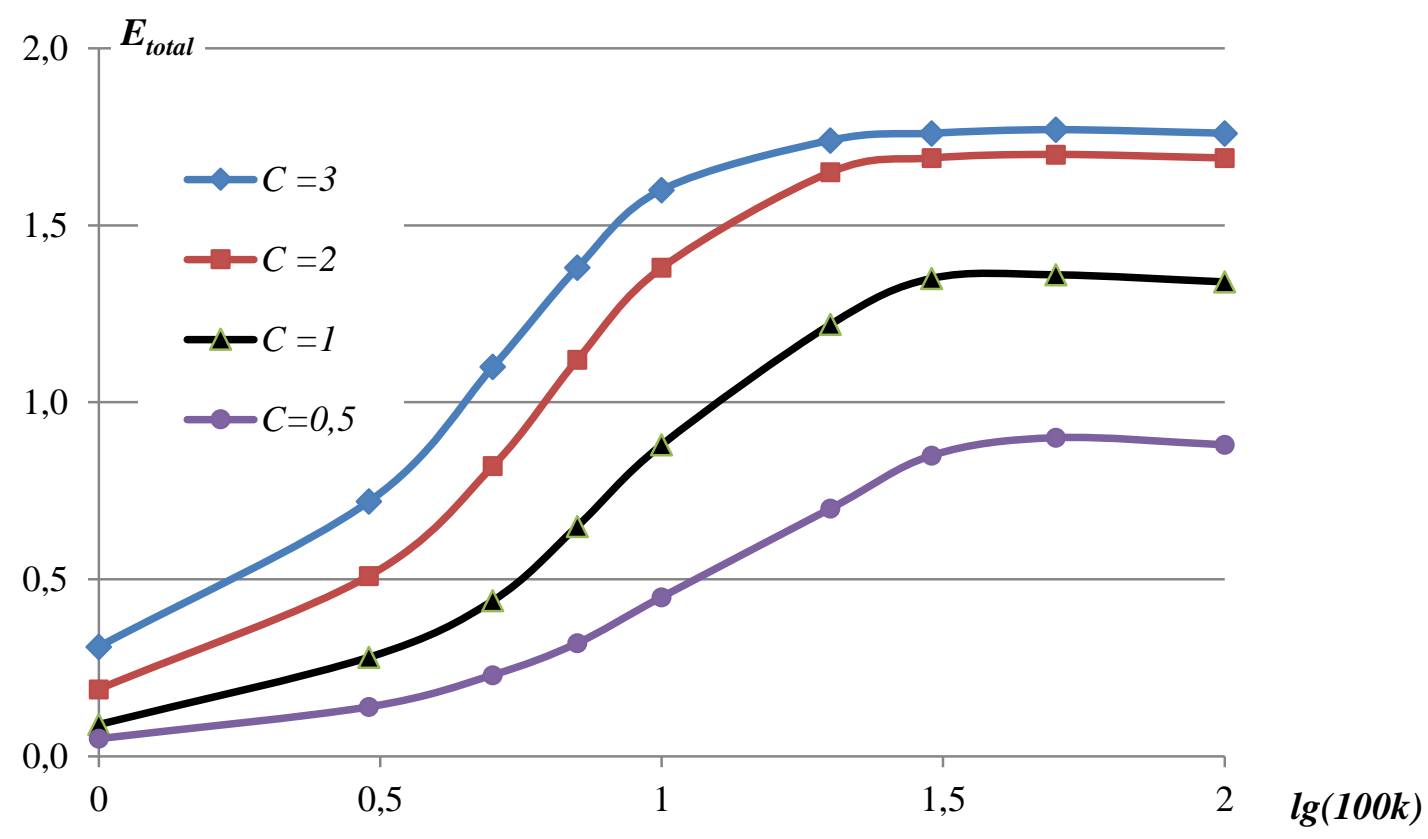

Рис. 3. Накопичення енергії на логарифмічній шкалі, в.о.

Fig. 3. Accumulation of energy on a logarithmic scale, relative units

Вплив ємності акумулятора на обсяги збереженої енергії помітний вже при значеннях, що дорівнюють годинній роботі ВДЕ 3 номінальною потужністю (для варіанту В1, C1 це становить до двох в.о.-год). Отже, зростання ємності акумулятора нелінійним чином пов'язане 3 можливостями збереження енергії, і зазначені ефекти характерні саме для умов багаторазової зміни напрямів енергетичного потоку до та від акумулятора. Іншим наслідком такого режиму роботи $\epsilon$ перевищення загальної збереженої енергії порівняно 3 одноразовим повним заряджанням акумулятора.

Для ілюстрації розглянемо цей же приклад (квітень, варіант В1, C1) при різних параметрах акумулятора. Так, при роботі практично без обмежень $(C=3, k=1)$ середній заряд акумулятора $C_{a v}$ становив би 0,55 , а загальна збережена енергія в середньому дорівнює 1,76. Очевидно, тут можливості акумулятора не використані повністю. При меншій ємності $(C=1)$ середній заряд становить $C_{a v}=0,403$ високою вірогідністю повної зарядки акумулятора, а середнє збереження енергіï: $E_{\text {total }}=1,35$. Тут можливості акумулятора практично повністю використовуються, а збережена енергія майже чотирикратно перевищує середній заряд. Таке саме співвідношення збережеться i в разі обмеження на швидкодію $(k=0,1)$ : середній заряд $C_{a v}=0,23 ; E_{\text {total }}=0,91$. Помітно, що обсяги збереженої енергії зменшуються, відповідно зростають втрати. Для ємності $C=0,5$ без обмежень на швидкодію $(k=1)$ маємо: $C_{a v}=0,23$; $E_{\text {total }}=0,87$. Очевидною $\epsilon$ висока ймовірність переповнення ємності, яка ще зростає в разі зменшення швидкодії $\left(C_{a v}=0,13 ; E_{\text {total }}=0,51\right.$ при $k$ $=0,1)$, проте співвідношення загальної збереженої та середньої накопиченої енергії лишається близьким до попереднього (4 до 1).

Приклад поведінки окремих складових випадкового процесу зображено на рис. 4. У відносних одиницях наведено поточний впродовж доби баланс потужностей $p_{i j}$ («баланс»), поточний стан зарядки акумулятора $C_{i}$ («стан акумул.»), а також суто позитивну складову акумулювання енергії «заряд.», тобто процес зарядки (на рисунку значення $E_{\text {total }}$ під час витрачання накопиченої енергії зображено горизонтальною лінією). Величина $E_{\text {total }}$ визначає загальну кількість збереженої енергії, включаючи повторні цикли, і визначає загальну ефективність енергосистеми. 


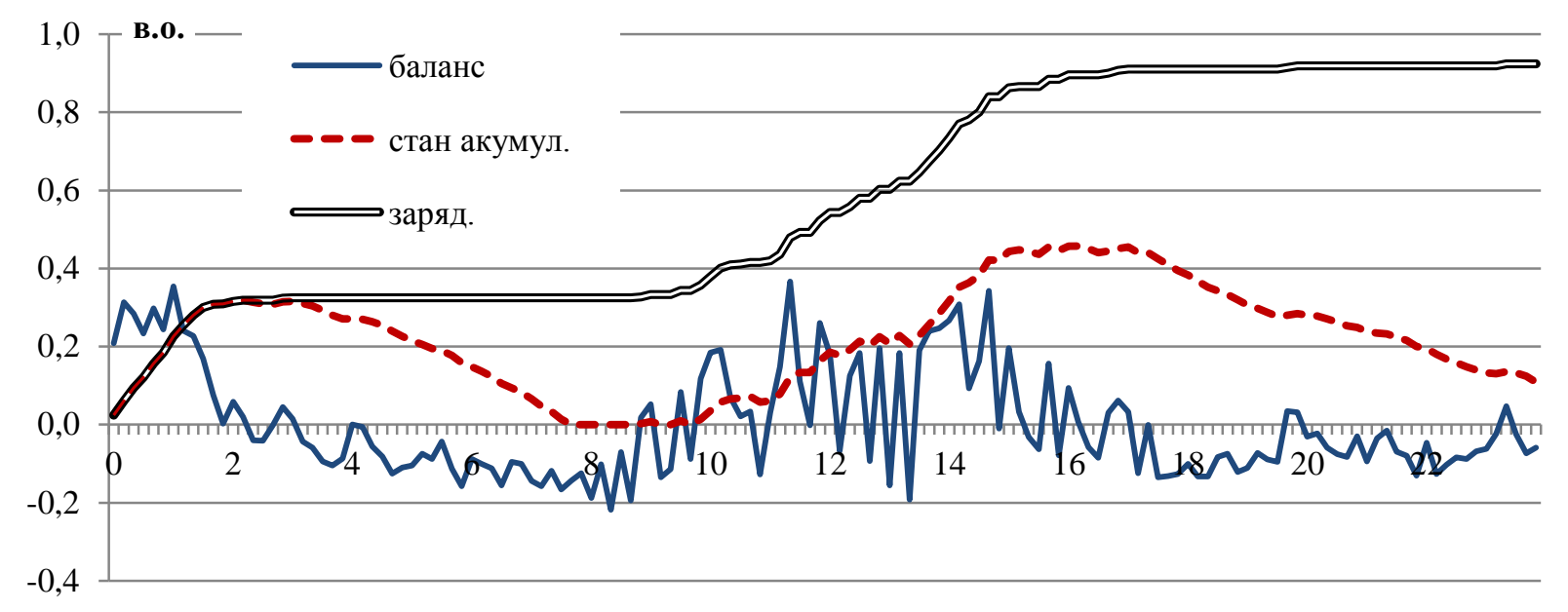

Рис. 4. Приклад добового процесу генерування та накопичення енергії

Fig. 4. Example of energy generation and storage daily process

Наведені результати стосуються повних обсягів енергопотоків, що не враховують втрат при перетворенні енергії. Якщо накопичення енергії відбувається 3 певною ефективністю, яку можна оцінити коефіцієнтом корисної дії (ККД), то обсяг акумульованої енергії пропорційно зменшиться. В реальності перетворення електричної енергії на іншу (хімічну, механічну) та зворотне перетворення можуть відбуватися 3 різною ефективністю, тому за ККД приймається підсумковий результат (після подвійного перетворення). При цьому значення ККД можуть бути залежними від ступеня зарядки та інших факторів. Аналітичне дослідження сукупності взаємопов'язаних випадкових процесів неможливе за відсутності точного опису випадкових параметрів, оскільки самі ці параметри є динамічними величинами, а їх оцінка залежна від доступної скінченої вибірки даних. Якісну поведінку процесів можна описати математичним моделюванням, а імітаційна модель дає оцінку числових значень. В лінійному наближенні показник ККД вважається постійним, залежним від типу акумулятора. Так, для електрохімічних акумуляторів застосовують значення 75-90 \% (свинцеві), 80-95 \% (літієві), для ГАЕС це 70-80\%, для водневого циклу «електролізер-паливний елемент»- 35-40\% $[15,16]$. Баланс енергій при цьому зміститься на величину втрат у від'ємну область, отже, для оптимального балансування потрібно заздалегідь передбачити збільшення планового графіка генерації. Це збільшення також не буде повністю лінійно залежним від ККД, оскільки залежатиме від кількості та глибини перезаряджань акумулятора (зміни напряму потоку енергії) впродовж досліджуваного часового циклу.

Висновки. Використана математична модель дає змогу виконати імітаційне моделювання випадкових процесів та отримати результати, що описують якісну поведінку та відносні значення досліджуваних величин. Встановлено, що ефективність акумулювання енергії має істотну залежність від ємності АКБ, натомість швидкодія менш важлива при тих темпах зміни потужності, які притаманні вітровій енергетиці або іiі комбінації 3 сонячною. Особливістю комбінованих енергосистем з ВДЕ є багатократність циклів зарядки/розряду акумуляторів. Потреба в акумулюванні для забезпечення надійного енергетичного балансу істотно (в рази) залежить від можливості прогнозування генерації ВДЕ, за якою формується плановий графік навантаження на енергосистему. Енергетична ефективність акумуляторів, тобто рівень втрат при перетворенні видів енергії, має враховуватися під час визначення потреб в корисній ємності, але точне врахування в рамках 
даної моделі допускає лише лінеаризоване представлення енергетичних процесів. Точний опис динамічних процесів накопичення та повторного використання енергії потребує подальших досліджень.

Стаття підготовлена в рамках виконання проєктів науково-технічних робіт Національної академії наук України: «Комплекс-С», «Комплекс-3» (КПКВК 6541030).

1. Obukhov S., Ibrahim A., Tolba M.A., El-Rifaie A.M. Power balance management of an autonomous hybrid energy system based on the dual-energy storage. Energies. 2019. Vol. 12. doi: $10.3390 /$ en 12244690 .

2. Olatomiwa L., Mekhilef S., Ismail M.S., Moghavvemi $M$. Energy management strategies in hybrid renewable energy systems. A review. Renewable and Sustainable Energy Reviews. 2016. Vol. 62. Pp. 821-835.

3. Salas, V., Suponthana, W., Salas R.A. Overview of the off-grid photovoltaic diesel batteries systems with AC loads. Appl. Energy. 2015. Vol. 157. Pp. 195-216.

4. Hu X., Martinez C.M., Yang Y. Charging, power management, and battery degradation mitigation in plug-in hybrid electric vehicles. A unified cost-optimal approach. Mech. Syst. Signal Process. 2017. Vol. 87. Pp. 4-16.

5. Jakhrani A.Q., Othman A., Rigit A.R.H., Samo S.R. Life cycle cost analysis of a standalone PV system. International Conference on Green and Ubiquitous Technology. Jakarta. Indonesia. 7-8 July 2012.

6. Narvaez A., Cortes C., Trujillo C.L. Comparative analysis of topologies for the interconnection of batteries and supercapacitors in a Hybrid Energy Storage System. In Proceedings of the 2017 IEEE 8th International Symposium on Power Electronics for Distributed Generation Systems (PEDG). Florianopolis. Brazil. 17-20 April 2017.

7. Choudar A., Boukhetala D., Barkat S., Brucker J.-M. A local energy management of a hybrid PV-storage based distributed generation for microgrids. Energy Convers. Manag. 2015. Vol. 90. Pp. 21-33.

8. Wu T., Shi X., Liao L., Zhou C., Zhou H., Su Y. A Capacity Configuration Control Strategy to Alleviate Power Fluctuation of Hybrid Energy Storage System Based on Improved Particle Swarm Optimization. Energies 2019. Vol. 12(4). Pp. 1-11. doi: 10.3390/en12040642.

9. Bocklisch T. Hybrid energy storage systems for renewable energy applications. Energy Procedia. 2015. 103 p.

10. Battery Storage for Renewables. Market Status and Technology Outlook. IRENA. Abu Dhabi. 2015. Vol. 32.

11. István Táczi. Overview of the Energy Storage Possibilities to Support the Electrical Power System. Research Paper. ERRA Budapest. 2016. 47 p.
12. Кузнєцов М.П., Мельник О.А., Смертюк В.М. Моделювання процесу акумулювання електроенергії в комбінованій енергосистемі. Відновлювана енергетика. 2020. № 4. C. 22-30.

doi: 10.36296/1819-8058.2020.4(63).22-30.

13. Lysenko O., Kuznetsov M., Chebanov A., Adamova S. Hybrid Power System Stochastic Optimization. In Springer eBook «Modern Development Paths of Agricultural Production: Trends and Innovations». 2019. Pp. 385-394.

doi: 10.1007/978-3-030-14918-5.

14. Kuznietsov M., Vyshnevska Y., Brazhnyk I., Melnyk O. Modeling of the Generation-Consumption Imbalance in the Heterogeneous Energy Systems with Renewable Energy Sources. 2019 IEEE 6th International Conference on Energy Smart Systems (ESS) conference-paper. Pp. 196-200.

doi: 10.1109/ess.2019.8764189.

15. Energy Storage Association. [Електронний ресурс]. URL: http://energystorage.org. (дата звернення: 15.09.17).

16. Korpikiewicz J. The Optimal Choice of Electrochemical Energy Storage Parameters. Acta Energetica 1/26. 2016. Pp. 56-62.

\section{REFERENCES}

1. Obukhov S., Ibrahim A., Tolba M.A., El-Rifaie A.M.. Power balance management of an autonomous hybrid energy system based on the dual-energy storage. Energies. 2019. Vol. 12. doi: 10.3390/en12244690.

2. Olatomiwa L., Mekhilef S., Ismail M.S., Moghavvemi M. Energy management strategies in hybrid renewable energy systems. A review. Renewable and Sustainable Energy Reviews. 2016. Vol. 62. Pp. 821-835.

3. Salas, V., Suponthana, W., Salas R.A. Overview of the off-grid photovoltaic diesel batteries systems with AC loads. Appl. Energy. 2015. Vol. 157. Pp. 195-216.

4. Нu X., Martinez C.M., Yang Y. Charging, power management, and battery degradation mitigation in plug-in hybrid electric vehicles. A unified cost-optimal approach. Mech. Syst. Signal Process. 2017. Vol. 87. Pp. 4-16.

5. Jakhrani A.Q., Othman A., Rigit A.R.H., Samo S.R. Life cycle cost analysis of a standalone PV system. International Conference on Green and Ubiquitous Technology. Jakarta. Indonesia. 7-8 July 2012.

6. Narvaez A., Cortes C., Trujillo C.L. Comparative analysis of topologies for the interconnection of batteries and supercapacitors in a Hybrid Energy Storage System. In Proceedings of the 2017 IEEE 8th International Symposium on Power Electronics for Distributed Generation Systems (PEDG). Florianopolis. Brazil. 17-20 April 2017.

7. Choudar A., Boukhetala D., Barkat S., Brucker J.-M. A local energy management of a hybrid PV-storage based distributed generation for microgrids. Energy Convers. Manag. 2015. Vol. 90. Pp. 21-33.

8. Wu T., Shi X., Liao L., Zhou C., Zhou H., Su Y. A Capacity Configuration Control Strategy to Alleviate Power 
Fluctuation of Hybrid Energy Storage System Based on Improved Particle Swarm Optimization. Energies 2019. Vol. 12(4). Pp. 1-11. doi: 10.3390/en12040642.

9. Bocklisch T. Hybrid energy storage systems for renewable energy applications. Energy Procedia. 2015. 103 p.

10. Battery Storage for Renewables. Market Status and Technology Outlook. IRENA. Abu Dhabi. 2015. Vol. 32.

11. István Táczi. Overview of the Energy Storage Possibilities to Support the Electrical Power System. Research Paper . ERRA Budapest. 2016. 47 p.

12. Kuznietsov M., Melnyk O., Smertiuk $V$. Modelyuvannya protsesu akumulyuvannya elektroenerhiyi v kombinovaniy enerhosystemi. [Simulation of electricity accumulation process in the combined power system]. Vidnovluvana energetika. 2020. No. 4. Pp. 22-30.

doi: 10.36296/1819-8058.2020.4(63).22-30.
13. Lysenko O., Kuznetsov M., Chebanov A., Adamova S. Hybrid Power System Stochastic Optimization. In Springer eBook «Modern Development Paths of Agricultural Production: Trends and Innovations». 2019. Pp. 385-394. doi: 10.1007/978-3-030-14918-5.

14. Kuznietsov M., Vyshnevska Y., Brazhnyk I., Melnyk O. Modeling of the Generation-Consumption Imbalance in the Heterogeneous Energy Systems with Renewable Energy Sources. 2019 IEEE 6th International Conference on Energy Smart Systems (ESS) conference-paper. Pp. 196-200. doi: 10.1109/ess.2019.8764189.

15. Energy Storage Association. [Electronic resource]. URL: http://energystorage.org (Applying date: 15.09.17).

16. Korpikiewicz J. The Optimal Choice of Electrochemical Energy Storage Parameters. Acta Energetica 1/26. 2016. Pp. 56-62.

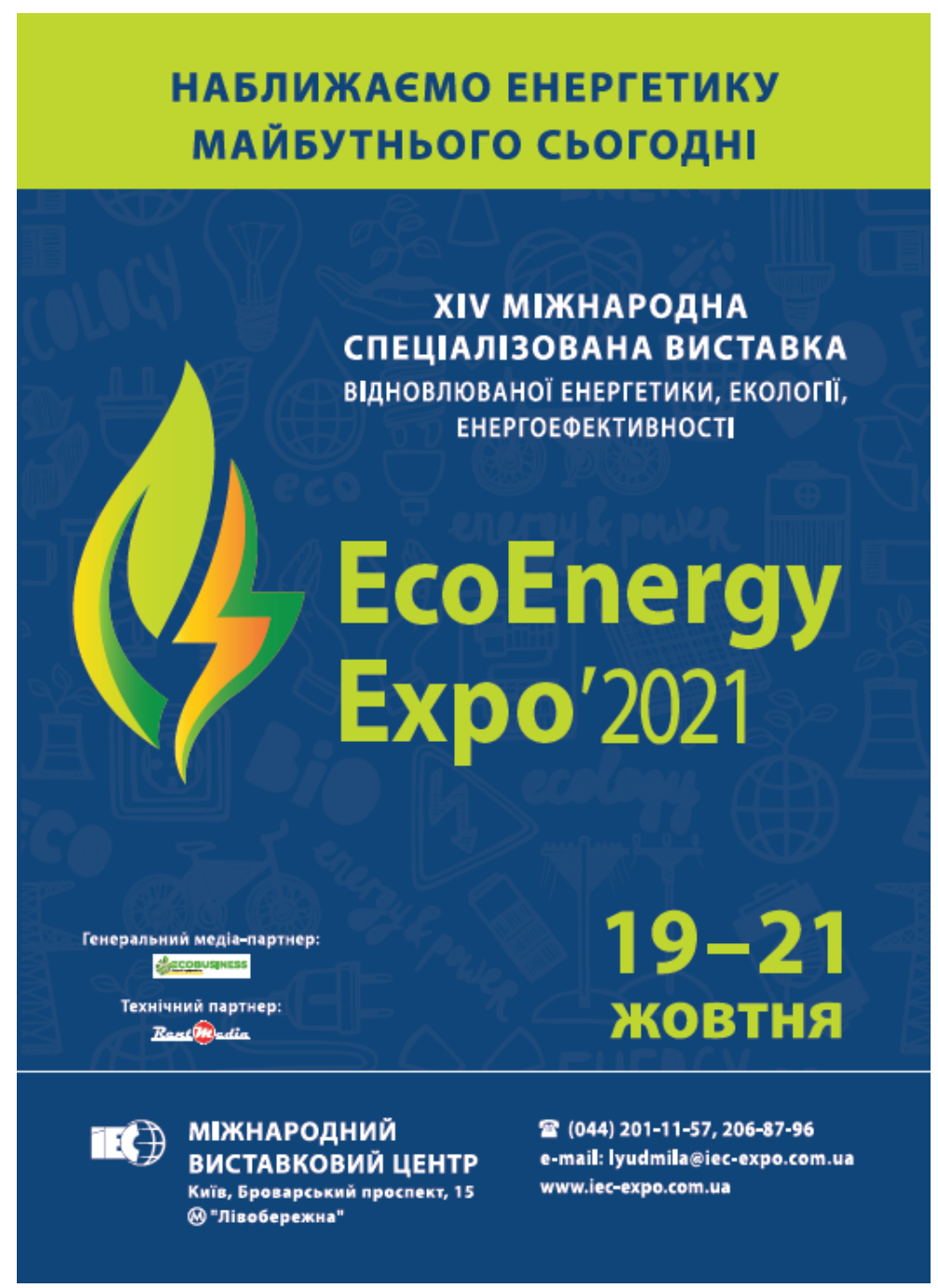

